\title{
Pockets of effectiveness: The contributions of critical political economy and state theory ${ }^{1}$
}

\author{
Giles Mohan
}

June 2019

${ }^{*}$ The Open University

Email correspondence: giles.mohan@open.ac.uk

ISBN: 978-1-912593-19-4

${ }^{1}$ This paper was produced for the ESRC-DFID project, 'Investigating Pockets of Effectiveness in Developing Countries: A New Route to Building State Capacity for Development'. 


\begin{abstract}
The pockets of effectiveness (PoEs) debates and political settlements literature are rooted in particular forms of political economy analysis. At one level, this is a positive contribution to the mainstream development policy literature, and allows us to characterise political systems and their power relations, as well as forcing us to pay close attention to the dynamics of state institutions. Yet, these literatures are disconnected from a tradition of more critical political economy analysis and state theory. This brief review is a first attempt to connect these bodies of theory, largely in an African context. We find some promising new (and old) avenues of inquiry to connect critical political economy to PoE work, largely in terms of various meso-level theories of how states function, which move us away from all-encompassing metatheories of the state. Such meso-level theories enable us to theorise the more fine-grained and developmentally positive institutions that constitute PoEs, since much of the meta-theory tends to be both broad brush as well as causally pessimistic, insofar as African states are rarely seen to engender positive developmental outcomes. These meso-level theories can also be more easily elaborated methodologically, which is vital, since most of the claims about state capacity and function require contextual empirical analysis.
\end{abstract}

Keywords: state theory, political economy, Africa, pockets of effectiveness, political settlements, agency

Mohan, G. (2019) Pockets of effectiveness: The contributions of critical political economy and state theory. ESID Working Paper No. 118. Manchester, UK: The University of Manchester. Available at www.effective-states.org

This document is an output from a project funded by UK Aid from the UK government for the benefit of developing countries. However, the views expressed and information contained in it are not necessarily those of, or endorsed by the UK government, which can accept no responsibility for such views or information or for any reliance placed on them. 


\section{Introduction}

The pockets of effectiveness (PoEs) debates and political settlements (PS) literature are rooted in particular forms of political economy analysis (Khan 2010, Roll 2015, Menocal 2015). At one level, this is a positive contribution to the mainstream development policy literature, which has tended to focus on institutional reforms devoid of an engagement with the underlying interests and power relations or, even, a fine-grained analysis of how existing institutions actually work. As a result, policy prescriptions often focus on normative visions of idealised political institutions, such as where the 'Norwegian model' of oil governance is recommended for a diverse set of new hydrocarbon economies, without accounting for the ways in which politics and institutions actually operate and, with it, any realistic sense of the possible (Le Billon 2012). So, the PoE and PS literatures do allow us to characterise state systems and their power relations, and force us to pay close attention to the dynamics of state institutions. Yet, these literatures are disconnected from a tradition of more critical political economy analysis and state theory. This brief review is a first attempt to connect these bodies of theory, largely in an African context where ESID's PoE case studies are located.

In reviewing the African state theory literature, what was striking was that very little has been done of late. The 1970s saw much on the 'dependent' state, whereas the 1980s were more dominated by the 'state-in-society' perspectives and then there was a long period of work on failed states, which evolved out of the earlier ideas that African states were 'disconnected' from their societies. The most recent critical work has been critiques of the failed state paradigm that has pervaded much analysis and policy around African governance for the past 20 years, yet there is little that moves beyond this critique.

There are, however, some promising new (and old) avenues of inquiry to connect critical political economy to PoE work, largely in terms of various meso-level theories of how states function, which move us away from all-encompassing meta-theories of the state (summarised in Table 1 in the Conclusion). Such meso-level theories enable us to theorise the more fine-grained and developmentally positive institutions that constitute PoEs, since much of the meta-theory - as we will see - tends to be both broad brush as well as causally pessimistic, insofar as African states are rarely seen to engender positive developmental outcomes. These meso-level theories can also be more easily elaborated methodologically, which is vital, since most of the claims about state capacity and function require contextual empirical analysis.

In terms of development, PoEs need to be assessed for their contribution to inclusive forms of development (Hickey et al. 2015, Mitra and Das 2018). Some PoE analysis judges them on their own terms, to the extent that a particular state institution fulfils its organisational mandate. Allied to this, PoEs are also analysed in relation to other agencies within the same state system under study to determine their relative effectiveness vis-à-vis generally weak institutions. Added to this, we need to assess 
PoE performance against some benchmark of inclusive development (Teichman 2016, OECD 2015).

The paper takes as its starting point two schools of thought around the African state that have been influential in the past four to five decades; namely, neo-Marxian and Weberian approaches. By critiquing these ideas and juxtaposing them to Mamdani's more Gramscian take on African governance, I explore approaches which seek to retain axes of structure and agency, and which situate state institutions and politics within an analysis of contemporary capitalism. These meta-theories are useful, but do not give us many concrete handles for addressing the more meso- and micropolitics of actually existing state institutions. So, the next section examines various meso-level theories, before concluding with suggestions towards some sort of productive synthesis.

\section{Marxian readings of the state}

Orthodox Marxist theory of the state saw the state as only and always acting in the interests of the 'whole bourgeoisie'. The monopoly of violence would, it was argued, be deployed to defend the bourgeoisie from its enemies. The idea of 'relative autonomy' broke from this position somewhat by arguing that the state can, at times, act independently of the desires of the ruling class, which is often referred to as Bonapartism, after the period of French history in the mid-19th century. In the period of African liberation and the ensuing early post-independence years, there was renewed interest in these questions of the role of the bourgeoisie, which was given a fillip by the work of Milliband in the late 1960s (Milliband 1969) and taken up by Hamza Alavi in the early 1970s.

Alavi's (1972) famous work on Pakistan and Bangladesh argued that while the state in post-colonial societies may be independent from any given class, in a class society the state must remain the protector of the socially dominant class. Crucially, for Alavi, the key issue for post-colonial states is that the state was imposed by the colonisers, in order to dominate indigenous social classes. While these countries possess a small indigenous bourgeoisie the ultimate ruling class is located outside these countries. Alavi saw the post-colonial state as having to mediate between the metropolitan ruling class, the indigenous bourgeoisie and the landed classes - which all had different interests - but also acting to preserve the social order in which all three groups' interests are embedded. This social order is fundamentally capitalist and so preservation of private property and the mechanisms for appropriation were key.

Africanists then debated throughout much of the 1970s the extent to which postindependence states followed Alavi's thesis. Leys' (1975) analysis of Kenya initially argued along a Bonapartist line, whereby the Kenyan bureaucracy was independent of particular classes, yet relied on class support and so had to juggle the tensions of nurturing such classes for their support, but not allowing them to become too powerful. Later, Leys (1978) changed his view, seeing the indigenous Kenyan 
bourgeoisie as genuinely seeking to supplant the neo-colonial bourgeoisie. This fomented a heated debate about the wider nature of 'dependency', since Leys' revised position suggested more optimism than orthodox dependency theories allowed. Further studies dug down into capital ownership to gauge how far an indigenous bourgeoisie had formed, with the conclusion being that domestic capitalists were always entwined with foreign capital. This entwinement enabled the penetration of African economies, and in disputes the neo-colonial state would side with foreign capital against domestic local capitals. Beckman (1980) criticised the debate for over-playing the role of the state as an instrument of fractional interests rather than focusing on its function as determined by 'non-functional' requirements of capital accumulation.

By the early-mid 1980s, with most African states in a protracted crisis, these debates gave way to more internally focused concerns around the functioning of states, such as questions of corruption (Bayart 1993). For analysing PoEs, these Marxian debates usefully focus on the relationship between international imperialist forces and the shape and direction of domestic politics. They bring to light the contradictions that African states are caught in and seek to manage, and in which parts of the bureaucracy function in the interests of both foreign and domestic capital. However, these strengths are also the weakness, since the level of abstraction ends up trying to pigeonhole quite distinct and different states into a single framework.

\section{Cultural and political explanations}

The seeming 'failure' and 'dysfunctional' nature of the African state that became apparent in the 1970s saw a growth in theories of political culture and systems of rule (Chazan 1988, Midgal 1994). Over the past 25 years, though the antecedents are much longer, African states have been framed by a neo-patrimonialist analysis, which saw 'culture' as the reason for developmental failure. Here I briefly critique these approaches, which have limited value for PoE, since they argue African states are inherently ineffective.

\section{The long shadow of Weber}

In terms of the relationship between politics, state and development, much analysis of the past 20 years has been framed by the failed state paradigm that largely rests on a particular reading of Weber. The focus on patrimonialism has tended to tar all African polities with the same brush (Allen 1995), as epitomised in Kaplan's infamous The Coming Anarchy (1994). This spatial aggregation also treats diverse African societies as temporally fixed, insofar as the forms of authority which constitute (neo)patrimonialism are seen as distinct and deeply rooted (Bratton and Van de Walle 1994).

While Weber saw patrimonialism as denoting rule via personal ties, it has become more associated with corruption and predation, and is contrasted with 'rational legal' authority as the supposed hallmark of Western polities (Wai 2012). Pitcher et al. (2009, Wai 2012, Cox and Negi 2010) argue that (neo)patrimonialism has become a 
catch-all for a diverse set of issues, including social relations, rent-seeking behaviour, blurring of the public service-private gain divide, and a classification of regime type. These culturalist accounts - Hibou (1999), Chabal and Daloz (1999) - argue that the 'social capital' of the state is inherently patrimonial and that this stifles development (Fine 1999).

By fundamentally locating patrimonialism in social relations, these forms of analysis tend to locate such behaviour in pre-colonial traditions or the coercive practices of colonialism. Such temporal logics create a path dependency in which African states are locked into practices which undermine development. Normatively these states are seen as 'failed', rather than 'unfinished political projects' (Wai 2012); the latter referring to the double standard of analysis, which sees violent periods of Western history as part of a rational move to full statehood, whereas for African polities such periods are deemed pathological. By such logic, a PoE could not really develop, since African states are by their inherent nature predatory and ineffective. There might be a possibility of squaring this circle, in that an effective institution could be created as a rent-seeking vehicle, but this opens up the whole question of what we mean by 'effectiveness' and how it relates to 'inclusive development'. An institution which is effective but only serves a narrow set of elite interests is arguably not developmental. Moreover, Pitcher et al. (2009) argue that Weber was more nuanced in his analysis of patrimonialism, since the active and 'voluntary compliance' of the governed is often overlooked in the rush to focus on domination. By doing this, these authors argue patrimonialism may incorporate a set of accountability mechanisms, such that 'informal institutions such as patron-client relations or personal ties can complement and even reinforce formal institutions associated with democracy and rule of law while remaining distinct from them' (p.144). This observation points to a more hybrid and varied set of relationships between rulers, institutions and citizens, in which claims-making and holding to account are exercised in multiple, innovative ways (Robbins et al. 2008, Lund 2016). This means we do not dispense with the idea of patrimonialism per se, but focus on how it is used by multiple actors to achieve political goals, rather than seeing it as a singular pathology feeding simplistic and singular goals.

\section{....and Gramsci}

In contrast to the culturalism of the (neo)patrimonialism literature are more political accounts. A more political account is found in Mamdani's 'bifurcated' state thesis (1996). Mamdani argues that colonial hegemony was based upon two distinct forms of rule - one based on indirect rule in the rural areas and one based on direct rule in urban areas. In the rural areas, customary authority was valorised and traditional authorities exercise mediated control based on logics of 'tribalism'. In urban areas, the rule was by colonial powers directly, with some limited co-option of local elites, based on a logic of race. Rights only really applied to colonial settlers and not indigenous Africans, so that anti-colonial struggles were led by these African urban elites, whereas the rural chiefs actively benefited from indirect rule and so were less 
keen to oppose it. Mamdani argues that such structures remain more or less 'intact' and condition contemporary African politics.

Mamdani's case was built up from an analysis of South Africa, but he argues that the model applies to all Africa, even if it was taken to its most 'scientific' extremes in South Africa. His analysis of the different forms of hegemony is important and nuances the blunter Marxian tendency of seeing colonial powers as dominating through force alone. The urban/rural divide is also interesting for seeing state authority as spatially differentiated and that the territoriality of state power is not singular or uniform. Cox and Negi (2010) argue that the bifurcation of Mamdani's thesis is too stark and that rural homelands were central to the reproduction of mining labour and effectively socialised (and so reduced the cost of) reproduction. In this sense, urban and rural were intimately linked through the distinct form of extractive capitalism that underpinned apartheid. What this points to is that the underlying political economy of capitalism shapes the forms of politics we see, rather than politics leading to underdevelopment, as in the Weberian accounts.

For thinking through PoE, arguably the chieftaincy system was relatively effective at achieving the goal of 'mediated hegemony' (Young 1994) and it was territorially extensive, which Roll (2015) sees as a feature of effectiveness. Yet it was an institution explicitly not designed for inclusiveness, nor for development, so it fails fundamentally as a PoE. Yet Mamdani's idea that different forms of institution function to perform different forms of rule is important and may help us understand some of the logics behind the creation and sustenance of particular PoEs in particular contexts.

Something that both the Weberian and Gramscian approaches share is to argue that the 'weak' or 'bifurcated' state engenders 'poor' development. The causal arrow points from the state to (under)development. For analysing PoEs, this is problematic if we argue that PoEs do manage to engender development. Relatedly, both approaches are quite path dependent, insofar as African 'culture' locks states into particular behaviours or insofar as colonial divide-and-rule policies structure contemporary African governance. How can we account for examples of state-led development success? And how do we explain cases where state trajectories have changed and seemingly broken out of their path dependency?

\section{Relational political economy - meta-theory}

One starting point to answer these questions is to focus on the wider political economy and the relationships between the state and capitalism. Here the causal arrow is less about weak states bringing about poor development and more a twoway street, though one that generally reverses the causal arrow by arguing that poor development shapes political structures. Put another way, capitalism at a particular stage requires certain political structures and processes.

Cox and Negi (2010) argue that: 
'it is the process of capitalist development that should be at the centre of our interpretation when we try to understand political development in Africa, but elsewhere in the world. The obstacles to capitalist development in the subcontinent are the key to its political specificity' (p.76).

They go on to say that African capitalism has been 'stunted' and its spread across the continent has been uneven. Key here has been the access to land for many Africans, which prevents them becoming fully proletarianised. The embeddedness of Africans in such a land economy also resulted in tensions over the degree of 'detribalisation', since capitalism benefited from the social reproduction of labour in the rural areas and so encouraged migrant labour. The result politically is that 'Anxieties over the maintenance of political stability have continually trumped the project of an autonomous process of capitalist accumulation' (p.78). Here, then, the stage of capitalist development shapes political processes, but once in place the political processes tend to militate against transformation of capitalism, which is a similar argument to Khan (2010), which I discuss below. As such, the clientelism analysed by the Weberians is an outcome of the political economy and not a cause of it. While external forces are important, Cox and Negi (2010) argue that they have not been as instrumental as some forms of neo-Marxist analysis argue.

The thrust of this theorisation is that, while capitalism can shape political institutions, the specific relationships are multiple and that there are feedback mechanisms between the political and the economic. It is the latter point - how the political shapes the economic - that has been the focus of neo-patrimonialism. Having accepted that the causal mechanisms linking capitalism and the state are diverse, then we cannot adopt singular theories which explain the many different contexts we see across Africa or within a single African state. It also means that the relationships between the state and economy are not fixed, but constantly being re-negotiated - which points to an analysis of the state as a more hybrid, relational and emergent set of institutions (Hagmann and Peclard 2010, Lund 2016, Jessop 1990).

Here Jessop's (1990) strategic relational approach is a useful framing device. He argued:
'since capitalism exists neither in pure form nor in isolation, states in capitalist societies will necessarily differ from one another ... (so that the aim is) ... explaining how the different systems come to be articulated in a contingent, non-necessary manner which sustains capital accumulation'.

The state is seen as an 'ensemble of institutions and organisations whose socially accepted function is to define and enforce collectively binding decisions on the members of a society in the name of their common interest or general will' (p. 341). These ideas of common interest and general will link states to development, insofar as states do not operate through domination or violence, although the elaboration of 
such common interests is always fluid and, like the state, always in a process of becoming. The idea of an ensemble means a wide variety of political institutions orbit around the core of the state, so that the boundaries between the state and non-state are always porous and uncertain and the state can never achieve full separation from society. Hence the boundaries between 'state' and 'society' are porous and the operations of states 'depend on a wide range of micro-political practices dispersed throughout society but concentrated and condensed in the core of the state' (p.342). How such institutions articulate with the state depends on the nature of the wider social formation and its history, such that advanced capitalism, say, is different to feudalism. The issue then is how to analyse the 'contingent, non-necessary' sustenance of capital accumulation and the role that agency plays in such political processes, which I develop in the next section.

Analytically Jessop proposes a conceptual hierarchy of three levels that are useful in understanding PoEs, particularly the last two of them. The first level is the state's basic institutional separation from the society it represents. This might be about linking specific modes of production to types of state, though this could be too blunt, given that multiple logics persist within a single mode of production (Gibson-Graham 1996). The second level is the nature of its internal organisation, modes of political calculation and operating procedures. This would focus on forms of representation and articulation, territorial and functional reach, distribution of powers among various state institutions, etc. (Jessop 1990: 344-346). The third level concerns the practices and discourse in and through which common interests are articulated and promoted.

\section{Coalitions, practices, negotiations and agency - meso-theory}

A frustration of Jessop's work is his lack of empirical grounding, such that it is difficult to easily deploy his conceptual framework analytically in concrete situations. But there are other theoretical framings which we can use to flesh out some of his arguments. On the whole, these are more meso-level theories, which largely, though not exclusively, deal with the second and to a lesser extent third levels of Jessop's hierarchy - internal organisation and operating procedures. Crucially though, we have to be aware of the relationships between all levels of the hierarchy. Khan's political settlements approach, with which I begin, actually focuses on all levels and begins, following Cox and Negi (2010), with a consideration of the form of capitalism which shapes political structures and processes in the developing world.

\section{Political settlements}

For Khan (2010: 1), a 'political settlement emerges when the distribution of benefits supported by its institutions is consistent with the distribution of power in society'. By focusing on the underlying power arrangements that underpin the emergence, stability and performance of institutions, political settlement theory pushes development thinking beyond the normative institutionalism of good governance discourse to examine coalitional politics at the heart of the state. An important contribution of this concept is the primacy it accords informal institutions for understanding governance and development outcomes in developing countries, 
where the clientelistic nature of politics is widely acknowledged. Khan (2010) sees clientelism as the most pervasive form of politics in developing countries, because the productive economy is not developed enough to allow allocation of resources through more formal mechanisms. In turn, tax revenues are insufficient for redistribution according to socially accepted rules to fund social sectors and other support for the economy that would build the state's legitimacy and secure the social contract. Instead, coalitions rely on informal political mechanisms regarding their relations with actors lower down the political hierarchy, or with capitalists outside the state, in order to survive. In this sense, clientelism is not a vestige of 'pre-modern' forms of politics, but rather a rational mode of politics, given the need to ensure the stability and viability of the ruling coalition.

Khan argues that the differing levels of capacity and commitment of ruling elites to delivering development are explained largely by the strength of excluded elite groups and of lower-level factions within ruling coalitions. In clientelist states, 'significant holding power is based on sources outside the incomes generated by formal institutions' (Khan 2010: 53 original emphasis). For Khan, 'holding power' refers to the capacity of individuals or groups to inflict costs on others and, reciprocally, to absorb costs imposed on them in repeated rounds of conflict. Holding power is not simply derived from wealth, but also from groups' organisational capacities. Where factions with significant holding power are excluded from the ruling coalition, then those in power are vulnerable to threats to their rule, which reduces the likelihood that they will undertake institutional reforms and distribute resources in the national interest. In contrast, where excluded elite coalitions are weak, the ruling coalition will consider itself secure enough to develop and, crucially, seek to implement a longerterm vision for the nation. In such circumstances, the need to fire-fight multiple threats to the ruling coalition is reduced and so the ability to pursue longer-term visions is enhanced.

Khan (2010) sees these vertical and horizontal distributions of power as productive of a range of types of political settlements. Competitive clientelism occurs 'where there is a substantial level of fragmentation in the distribution of power across political organizations and within the ruling coalition such that higher levels have more limited powers over lower levels' (Khan 2011: 48). In such contexts, ruling elites are vulnerable, due to the strength of excluded elite factions, as well as of lower level factions within the ruling coalition. In addition to the distribution of power and the coalitions' organisational capabilities are the relations that the coalitions have with domestic capitalists. Whitfield and Therkildsen (2011) argue that the relationship between ruling elites and domestic capitalists is shaped by the sources of financing on which the the elites rely. If ruling elites rely on inward foreign direct investment (FDI) to generate state revenue through taxation or to earn foreign exchange, then firms in these sectors will receive the most attention. This is a fine balancing act, since political coalitions need relatively strong capitalists to supply such support, but do not want them to be so powerful as to challenge the dominance of the ruling coalition. The political influence of domestic firms comes largely from their wealth, 
since it can provide resources for buying access to decision-making processes (Hirvi and Whitfield 2015).

The idea of political settlements is useful for analysing PoE, since it situates politics within a particular form of capitalist development and links power relations to institutional form and function. For developing economies that are often aid dependent and/or extraverted, political settlements tends to be too internalist and fails to analyse how transnational linkages of one form or another also constrain or enable elite actors. Political settlements also tends towards rational individualism, in which elites are presented as overwhelmingly motivated by regime survival - or short-term interests - and so negates the possibility that longer-term ideas about how development should unfold could inform political decisions.

Roll (2015) argues that PoEs can arise and be sustained, given certain conditions and that they do not seem to be simply sources of rents. An important contribution he makes is that PoEs (and by implication wider developmental politics) are not just about interests, but the imbrication of interests and ideologies. He notes (p. 196) 'Political economy frameworks usually assume that political survival is the chief incentive behind most, if not all, things politicians do'. Roll analyses a more diverse set of motivations, which includes development ideologies, concern over peoples' lives, and concern about (international) reputation. In this sense narrowly interestbased political economies, like political settlements, are not enough and we need to focus on the links between interests, institutions and ideas. One limitation of political settlements theory is its rational actor interpretation of elite behaviour, where the behavior of powerful elites 'is driven primarily by pursuit of an inter-related set of economic and power interests' (Parks and Cole 2010: 8). While Khan notes that holding power can include the ability of actors to 'mobilise prevalent ideologies and symbols of legitimacy' (2010: 20), he sees ideas as only instrumental, consistent with a rational actor approach.

As Hindess (1990) notes, there is no necessary linkage between interests and social location, since actors' reasons for action are to a degree discursively determined, so we should not automatically 'read off' agency and interests from social location. Rather, ideological positions can constrain or modify the short-term material orientations of ruling coalitions. The rational actor perspective of political settlements theory tends to treat ideas merely as epiphenomena of interests. Yet a diverse body of theory examines the mutual construction of ideas and interests (Beland and Cox 2010, Hall 2010, Hudson and Leftwich 2014), such that 'the ideas that actors hold affect how they define their interests' (Campbell 2002: 22). From the perspective of our discussion of PoEs, we need to focus on the actual responses of elite actors to material reality, which is what Hay (2010: 68) refers to as 'rendering actionable' actors' concepts. Ideas are also 'embedded in the design of institutions' (Beland and Cox 2010: 8), such that the co-construction of institutions and ideas brings the stability inherent in institutions, yet this does not mean that ideas are always coherent or that institutions are incapable of being changed. Bebbington (2015) argues that, while institutions are difficult to shift, it is possible through coordinated efforts to 
change the rules of the game. As such, there are, then, likely to be multiple motivations for elite behaviour, so we need to think about social agency of various types.

\section{State agency and negotiation}

Where political settlements focuses on elite coalitions and factions, Wight focuses on agency and agents. His starting point is a rejection of methodological nationalism, which is central to international relations (IR), whereby states are treated in singular ways. Wight's argues that he is seeking to construct 'a structurally aware, although non-structuralist, theory of IR' (2004). The limitations of much IR theory is what Wight (2004) terms the 'as if' logic, whereby states are treated 'as if' they were people, rather than more variegated and contested entities, as in Jessop's account.

Here Wight (1999) develops a three-layered account of state agency. The first meaning of agency relates to the more commonsense view, in which agents have, following Spivak (1996), accountability, intentionality and subjectivity. This Wight terms 'agency ${ }_{1}$ '. However, as we are all reflexive and embedded actors, there is no pure ' $\mathrm{l}$ ' unencumbered by social forces, even if we are able to act. This notion of 'embodied intentionality' relates to Wight's second dimension - 'agency' ${ }_{2}$ - in which agents are 'an agent of something'. This social context refers to 'the socio-cultural system into which persons are born and develop' (p.133). There is a recursive aspect to this, since individuals can reproduce or transform these collective identities, although Wight acknowledges 'not all agents are equally placed or positioned' (p.133). The third dimension of Wight's framework is the roles that agents inhabit, although Wight prefers the term 'positioned practices', to reflect the non-normative aspect of this. However, these position practices - or agency ${ }_{3}-$ are structural insofar as they refer to properties that 'persist irrespective of the agents that occupy them' (p.133) and Wight uses the figure of the diplomat as an example. For Wight, any invocation of agency requires all three dimensions; that is, they are 'co-constituted' and can only be analysed empirically.

For PoEs, the idea of having both agents and 'positioned practices' opens up the possibilities of situating actors within more longer-standing institutions, whether these institutions are more informal/cultural or formal/organisational. While Wight's theory is 'structurally aware', it is not clear what sorts of structure really matter or what enabling or constraining role they place on agents. And unlike the calls for a more political economy approach, there is certainly no consideration of the stage of capitalist development as helping to explain the nature of political institutions that we see in practice.

In seeking to disaggregate the state and examine actually existing processes Hagmann and Peclard's (2010: 544) work is instructive in seeking to 'understand how local, national and transnational actors forge and remake the state through processes of negotiation, contestation and bricolage'. Their 'analytic of statehood' is about the dynamic and always undetermined, but not random, process of state 
(de)construction, which is a multi-level phenomenon. Their heuristic framework comprises diverse actors, many of whom lie outside formal political structures and the resources and repertoires they deploy in shaping their political authority. The process of negotiation takes place in particular political spaces, called 'arenas', which are often hard to locate and delimit. More focused and formalised processes occur at 'negotiating tables' and there are iterative links between the wider 'arena' and these more formal spaces. Such politics is also historically conditioned, with previous rounds of negotiation or stabilisation of a social contract shaping the playing field for subsequent negotiations. Doornbos (2010) rightly cautions against universalisation of the idea of 'negotiation', because there are many instances in African politics of 'negation', but Hagmann and Peclard's work is useful in capturing the changing balance of power in African polities.

Like Wight, Hagmann and Peclard open up the possibility for links between 'tables' and 'arenas', which is partly a question of political scale, but also about individuals within wider networks of power. For analysing PoEs, their framework views states as more emergent and contested, and gives us some empirical handle for examining concrete instances of negotiation or negation. The development of PoEs is the product of negotiation within the state and such a more fluid notion of negotiation means PoEs cannot be taken for granted. Rather, we see them as sites of contestation. Moreover, Hagmann and Peclard are much more attuned to international forces in shaping African politics, although they see the international as more open than simply transnational capital.

\section{Enclaves}

This question of international capital and domestic politics is at the heart of Ferguson's focus on enclaves. Speaking of resource extraction in Africa, Ferguson argues:

'this economic investment has been concentrated in secured enclaves, often with little or no economic benefit to the wider society ... see how different the political-economic logic of the privately secured enclave is from the universalizing grid of the modernist state' (2005: 378).

These 'secured enclaves' tend to be in the minerals sector with their gated compounds and limited linkages with the local economy. Ferguson contrasts the enclave model with a post-independence 'social' model, where mining houses often constructed company towns around a sense of paternalism and thereby had deeper roots in African societies allied to a developmental state agenda.

Associated with the newer enclaved mode of insertion into Africa is, Ferguson argues, a bifurcated governance model, in which the increasingly unusable formal state structures are 'hollowed out' fiscally and in terms of authority and personnel, while the usable enclaves are governed efficiently as private entities in a similar vein to pre-colonial mercantilist entrepots. What is interesting is how the usable and 
unusable are linked. These settlements are brokered at the elite level in ways that bypass channels of debate and accountability within African states and polities, suggesting that only parts of the African state are unusable (or at least rendered irrelevant).

Ferguson usefully situates African politics within a reading of global capitalism and sees enclaves as a way of linking a particular form of capitalism to particular forms of governance. In such a model, PoEs could be natural resource enclaves that are managed 'well' because they create sources of rents and are protected by political elites. There is much to this more spatially and institutionally nuanced reading of extraversion wherein these vehicles for rent capture are more narrowly interest- and class-based and so not particularly 'inclusive' or developmental, unless rents are redistributed more equitably. For PoE analysis, Ferguson urges us to examine different fractions of capital - some of which may be enclaved - and what role states play in enabling these to succeed, or how capital itself exploits (unintended) differences in institutions and policies. It is important to realise that capital is fragmented, so that state activity and politics cannot be homogenised by reducing it to the needs of a 'unitary' capital (Glassman 1999). Similarly, as the dependency theorists argued, international capital is never completely 'external', since it combines with fragments of local capital. The reality is that some 'economy' does exist within the country which the state presides over, so that the state does not simply perform 'municipal' functions on behalf of international capital. This is echoed by Ong (2008: 120), who notes that 'New spaces overlap but do not always match up with given administrative units, nor are they building blocs for an "ultimate" global space of capital'. Yet such sub-national and networked territorial logics require sovereign states to provide the necessary 'social infrastructure', whereby ruling elites create the conditions for the international mobility of capital, which requires granting access to resources and territories (Colàs and Pozo 2011).

\section{Practices}

Something of an outlier in terms of state theory, but one that compliments Jessop's work well and which could help us understand PoEs, is Painter's (2006) idea of state practices. While Jessop focuses on institutions that make up a relational understanding of the state, he rarely focuses on agency, invoking instead an abstract notion of 'social forces' to explain change. Painter seeks to insert more nuanced understandings of agency into state theory. His argument is that, contrary to globalisationists, the nation-state has not had its day. Equally, though, in seeking to understand the changing nature of the state, there has been too much analysis of 'big power' politics and not enough on 'prosaic geographies of stateness'. Like Wight, Painter challenges the reification of the state as 'a thing' to reveals states' 'hetereogenous, constructed, porous, uneven, processual and relational character' (p.754). By focusing on mundane and prosaic practices of stateness - things like local elections, engaging with healthcare services or schools, etc. - we see states as contested and re-made on an ongoing and micro-level. Such an approach breaks down the idea of a state 'suspended' above society, but rather posits that state 
practices permeate society in myriad ways. It also means that while state institutions clearly exist - courts, armies, schools, etc. - how far they contribute to statisation depends on their practices, as opposed to their presence as state institutions. The important corollary of this is that seemingly 'non-state' institutions can have state-like effects; such things as private businesses engaged in security. This focus on prosaic practices also allows for a more spatially uneven understanding of the state as territorially and socially variegated.

For PoEs, this idea of practices is interesting, because it not only challenges fixed and homogenous notions of the state, but focuses us on the micro-politics and practices of (re)constituting institutions at a range of scales. In this sense, Painter's work resonates with Hagmann and Peclard's, though Painter does not label the sites as being solely about negotiation. Painter also argues that a focus on state practices gets us into non-normative analyses of stateness, which is a problem, as we saw, that dogs the Weberian approaches; that Southern states are measured against a mythical Western ideal and found wanting. Instead, we can examine existing prosaic state practices and assess whether and how they contribute to a sense of stateness.

\section{Conclusion}

This review of various strands of state theory suggests that some of the meso-level theories set out in Section 5 provide insight into much more nuanced and openended political trajectories than both the Marxist and the neo-Weberian theories, as well as enriching Jessop's rather abstract and agency-less state theory. Some of these strengths and weaknesses are summarised in Table 1.

Much of the political settlements literature which we have used to frame PoE is somewhat methodologically nationalist. Its focus on elites and their rationality in pursuing clientelism in contexts of weakly developed capitalist economies is useful, but it does not see capitalism as an international system that enrols and constrains states and state actors. As such, the neo-Marxist literature is useful for examining the conditioning role of international capital and the ways in which domestic class forces and political elites are wrapped up in these contradictory processes. Jessop's work picks up on these dynamics, but equally has a more complex view of the state as an ensemble of institutions whose rationale and actions cannot be 'read off' from an abstract theory of capitalism. Mamdani, Wight, and Hagmann and Peclard's work - in quite different but complementary ways - gives some pointers to these more complex readings of politics. Mamdani focuses very much on the ways in which hegemony is exercised institutionally, legally and spatially, which is useful for unpacking actually existing institutions and their governance effects. Wight seeks to locate agency in multiple domains, rather than treating the state as a coherent actor, while Hagmann and Peclard focus on the concrete sites where politics is negotiated. Ferguson's work on enclaves also points to the spatiality of political-economy that links local to global, but he underplays the role of the domestic state in shaping enclaves or the ways in which social, political and economic relations 'leak' from 
Table 1: Theories of the state and PoE: A conceptual mapping

\begin{tabular}{|c|c|c|}
\hline Body of theory & Characteristics & Implications for PoEs \\
\hline \multicolumn{3}{|l|}{ Macro political-economy } \\
\hline Dependency (e.g. Alavi) & $\begin{array}{l}\text { - State serves } \\
\text { (international) capital } \\
\text { - Classes are weakly } \\
\text { developed and } \\
\text { dominant class is } \\
\text { comprador }\end{array}$ & $\begin{array}{l}\text { - Comprador elite } \\
\text { protects international } \\
\text { capital } \\
\text {-State geared to rent } \\
\text { capture and } \\
\text { suppression of class } \\
\text { forces }\end{array}$ \\
\hline $\begin{array}{l}\text { (Neo)patrimonialism (e.g. } \\
\text { Hibou) }\end{array}$ & $\begin{array}{l}\text { - States are riven by } \\
\text { 'African' forms of } \\
\text { authority }\end{array}$ & $\begin{array}{l}\text { •States are generally } \\
\text { ineffective, so PoEs } \\
\text { could not emerge } \\
\text { •Rather, networks of } \\
\text { neo-patrimonial 'social } \\
\text { capital' are dominant }\end{array}$ \\
\hline Gramscian (e.g. Mamdani) & $\begin{array}{l}\text {-Bifurcated political } \\
\text { institutions established } \\
\text { to divide and rule } \\
\text {-Urban/rural divide }\end{array}$ & $\begin{array}{l}\text { - Examines actually } \\
\text { existing institutions and } \\
\text { dynamics of hegemony } \\
\text { - Under-emphasises } \\
\text { wider capitalist system }\end{array}$ \\
\hline $\begin{array}{l}\text { Strategic-relational (e.g. } \\
\text { Jessop) }\end{array}$ & $\begin{array}{l}\text { - States generally reflect } \\
\text { and support capitalism, } \\
\text { but no necessary link } \\
\text { - States are ensembles } \\
\text { of institutions } \\
\text { - States sit in relation to } \\
\text { society and are not } \\
\text { separate from it }\end{array}$ & $\begin{array}{l}\text {-Understands states as } \\
\text { an ensemble of } \\
\text { institutions } \\
\text { - That state and society } \\
\text { are co-produced and so } \\
\text { emergent/contested }\end{array}$ \\
\hline \multicolumn{3}{|l|}{ Meso political economy } \\
\hline $\begin{array}{l}\text { Political settlements (e.g. } \\
\text { Khan) }\end{array}$ & $\begin{array}{l}\text {-Power balance } \\
\text { determines institutions } \\
\text { - Stage of capitalist } \\
\text { development shapes } \\
\text { possibilities for } \\
\text { (re)distribution } \\
\text { - Informality is key }\end{array}$ & $\begin{array}{l}\text { - Explains existence of } \\
\text { particular types of } \\
\text { institution } \\
\text { - Focuses on coalitions } \\
\text { and factions as } \\
\text { contesting role of these } \\
\text { institutions }\end{array}$ \\
\hline Agency (e.g. Wight) & $\begin{array}{l}\text {-Avoids reifying state as } \\
\text { single entity } \\
\text {-Agency distributed } \\
\text { within the state and }\end{array}$ & $\begin{array}{l}\text {-Agency located in } \\
\text { different sources } \\
\text {-Bridges the } \\
\text { structure/agency divide }\end{array}$ \\
\hline
\end{tabular}




\begin{tabular}{|c|c|c|}
\hline & $\begin{array}{l}\text { derived from different } \\
\text { positionings }\end{array}$ & \\
\hline $\begin{array}{l}\text { Negotiation (e.g. } \\
\text { Hagmann and Peclard) }\end{array}$ & $\begin{array}{l}\text { - State is emergent } \\
\text { - Ongoing negotiation of } \\
\text { power }\end{array}$ & $\begin{array}{l}\text { - States as } \\
\text { disaggregated } \\
\text {-Transnational forces } \\
\text { important }\end{array}$ \\
\hline Enclaves (e.g. Ferguson) & $\begin{array}{l}\text { - Global capitalism } \\
\text { arranged through 'lily } \\
\text { pads' } \\
\text { - Resource extraction } \\
\text { through enclaves } \\
\text { - Governance focused on } \\
\text { serving the 'usable' } \\
\text { enclaves }\end{array}$ & $\begin{array}{l}\text { - Effective resource } \\
\text { enclaves may exist, } \\
\text { and are protected, } \\
\text { which enable rent } \\
\text { extraction } \\
\text {-Outside of these, state } \\
\text { is unviable }\end{array}$ \\
\hline Practices (e.g. Painter) & $\begin{array}{l}\text {-Against reification of } \\
\text { the state } \\
\text { - Focus on prosaic state } \\
\text { practices } \\
\text { - Practices contributing } \\
\text { to stateness not } \\
\text { necessarily by 'state' } \\
\text { actors }\end{array}$ & $\begin{array}{l}\text {-States as contested } \\
\text { and re-made through } \\
\text { ongoing micro-practices } \\
\text { - Interplay of the micro- } \\
\text { and the institutional }\end{array}$ \\
\hline
\end{tabular}

such seemingly bounded spaces. Together these more spatial metaphors of sites, tables, enclaves, and (lily)pads resonate with the metaphor of 'pockets', in suggesting institutional locations where, for a variety of reasons, certain forms of effectiveness reside.

Yet, the dynamism of many of these theories also cautions us against path dependency arguments that suggest that effectiveness becomes hard-wired into particular institutions, because, as Jessop and Painter show, states are processes and are forever 'becoming', so that it is unwise to confer spatial or temporal closure on such political processes. I also particularly like Painter's work for examining how state effects can be achieved by 'non-state' actors and in the everyday actions of a range of actors. For me, this helps move us away from teleological readings of state functioning which ally institutional structure ' $x$ ' with outcome ' $y$ '.

Methodologically, following Allen (1995), the need is to focus on 'politics in Africa' and not 'African politics', for, as he notes, 'There is too much variation in politics in Africa ... for a single political structure or process to be adequate for the analysis of those histories" (p.302). He proposes historical phases that are not teleological, but more analytical. Such analysis rests on empirical specificity to give context and nuance, which is not the same as being empiricist and simply cataloguing different political forms and events. For example, the state failure paradigm treats the theory as given and then finds examples from Africa to support this (Allen 1995, Wai 2012). 
Likewise, excessively structuralist neo-Marxist accounts tended to hypothesise about the links between capitalism and the state and then select data to support this (Leys 1996). Allen's (1995) point about situating specific events in wider contextual framings is critical, so that we do not, for example, see coups d'etat as essentially the same, irrespective of where and why they arose. Wai (2012: 39) describes this as 'seeking to understand historical, social, and political transformations as processes'. For PoEs, this logic means that we have to trace out carefully the processes which led to their formation and the basis of their effectiveness, which is something Roll (2015) attempts to do. Yet, for an understanding of inclusive development, the overriding question is effective for whom. 


\section{References}

Alavi, H. (1972). 'The state in post-colonial societies: Pakistan and Bangladesh', New Left Review, 74:59-81.

Allen, A. (1995). 'Understanding African politics', Review of African Political Economy, 22(65): 301-320.

Bayart, J. (1993). The State in Africa: The Politics of the Belly. Harlow: Longman.

Bebbington, A. (2015). 'Governing natural resources for inclusive development', in S., Hickey, K. Sen, and B. Bukenya (eds.), The Politics of Inclusive Development: Interrogating the Evidence. Oxford: Oxford University Press.

Beckman, B. (1980). 'Imperialism and capitalist transformation: Critique of a Kenyan debate', Review of African Political Economy, 7(19): 48-62.

Beland, D. and Cox, R. (2010). 'Introduction: Ideas and politics', in D. Beland and R. Cox (eds.), Ideas and Politics in Social Science Research. Oxford: OUP Online.

Bratton, M. and Van de Walle, N. (1994). 'Neopatrimonial regimes and political transitions in Africa', World Politics, 46(4): 453-489.

Campbell, J. (2002). 'Ideas, politics and public policy', Annual Review of Sociology, 28: 21-38.

Chabal, P. and Daloz, J.-P. (1999). Africa Works: Disorder as Political Instrument. Oxford: James Currey Publishers.

Chazan, N. (1988). 'Patterns of state-society incorporation and disengagement in Africa', in D. Rothchild and N. Chazan (eds.), The Precarious Balance: State and Society in Africa. Boulder, CO: Westview Press.

Colás, A. and Pozo, G. (2011). 'The value of territory: Towards a Marxist geopolitics', Geopolitics, 16(1): 211-220.

Cox, K. and Negi, R. (2010). 'The state and the question of development in subSaharan Africa', Review of African Political Economy, 37(123): 71-85.

Doornbos, M. (2010). 'Researching African statehood dynamics: Negotiability and its limits', Development and Change, 41(4): 747-769.

Ferguson, J. (2005). 'Seeing like an oil company: Space, security, and global capital in neoliberal Africa', American Anthropologist 107(3): 377-382.

Ferguson, J. (2006). Global Shadows: Africa in the Neoliberal World Order. Durham, NC: Duke University Press.

Fine, B. (1999). 'The developmental state is dead - Long live social capital?' Development and Change, 30: 1-19.

Gibson-Graham, J. K. (1996). The End of Capitalism (As We Knew It). Oxford: Blackwell.

Glassman, J. (1999). 'State power beyond the "territorial trap": The internationalization of the "state"', Political Geography, 18(6): 669-696.

Hagmann, T. and Peclard, D. (2010). 'Negotiating statehood: Dynamics of power and domination in Africa'. Development and Change 41(4): 539-562.

Hall, P. (2010). 'Historical institutionalism in rationalist and sociological perspective', in J. Mahoney and K. Thelen (eds.), Explaining Institutional Change: Ambiguity, Agency and Power. Cambridge: Cambridge University Press, pp. 204-223. 
Hay, C. (2010). 'Ideas and the construction of interests', in D. Beland and R. Cox (eds.), Ideas and Politics in Social Science Research. Oxford: OUP Online.

Hibou, B. (1999). 'The "social capital" of the state as an agent of deception', in J. Bayart, S. Ellis and B. Hibou (eds.), The Criminalization of the State in Africa. Oxford: James Currey, pp. 69-113.

Hickey, S., Sen, K. and Bukenya, B. (eds.) (2015). The Politics of Inclusive Development: Interrogating the Evidence. Oxford: Oxford University Press.

Hindess, B. (1990). 'Analyzing actors' choices', International Political Science Review, 11(1): 87-97, 91.

Hirvi, M. and Whitfield, L. (2015). 'Public-service provision in clientelist political settlements: Lessons from Ghana's urban water sector', Development Policy Review 33(2): 135-158.

Hudson, D. and Leftwich, A. (2014). 'From political economy to political analysis'. Research Paper 25, Development Leadership Program (DLP). Birmingham, UK: University of Birmingham.

Jessop, B. (1990). State Theory: Putting Capitalist States in their Place. Cambridge: Polity Press.

Kaplan, R. (1994). 'The coming anarchy: How scarcity, crime, overpopulation, tribalism, and disease are rapidly destroying the social fabric of our planet', The Atlantic Monthly, 273(2): 44-76.

Khan, M. (2010). 'Political settlements and the governance of growth-enhancing institutions'. Working paper (unpublished). London: School of Oriental and African Studies, University of London. Available online at: http://eprints.soas.ac.uk/9968/ (accessed 5 February 2013).

Khan, M. (2011). The Political Settlement and Its Evolution in Bangladesh, unpublished working paper. Available at http://eprints.soas.ac.uk/12845/1/The_Political_Settlement_and_its_Evolution in_Bangladesh.pdf (accessed 15 February 2017).

Le Billon, P. (2012). Wars of Plunder: Conflicts, Profits and the Politics of Resources. New York: Columbia University Press.

Leys, C. (1975). Underdevelopment in Kenya: The Political Economy of Neocolonialism. London: Heinemann and James Currey.

Leys, C. (1978). 'Capital accumulation, class formation and dependency: The significance of the Kenya case', Socialist Register, 15.

Leys, C. (1996). The Rise and Fall of Development Theory. Nairobi: EAEP; Bloomington, IN: Indiana University Press; and London: James Currey.

Lund, C. (2016). 'Rule and rupture: State formation through the production of property and citizenship', Development and Change, 47: 1199-1228.

Mamdani, M. (1996). Citizen and Subject: Contemporary Africa and the Legacy of Late Colonialism. Oxford: James Currey.

Menocal, A. R. (2015). Political Settlements and the Politics of Inclusion. The State of the Art, No.7. Development Leadership Programme (DLP). Birmingham, UK: University of Birmingham.

Migdal, J. (1994). 'The state in society: An approach to struggles for domination', in J. Migdal, A. Kohli and V. Shue (eds.), State Power and Social Forces: 
Domination and Transformation in the Third World. Cambridge: Cambridge University Press, pp. 7-34.

Miliband, R. (1969). The State in Capitalist Society. London: Weidenfeld and Nicolson.

Mitra, A. and Das, D. (2018). 'Inclusive growth: Economics as if people mattered'. Global Business Review, 19(3): 756-770.

OECD (2015). All on Board: Making Inclusive Growth Happen. Paris: OECD.

Ong, A. (2008). 'Scales of exception: Experiments with knowledge and sheer life in tropical Southeast Asia'. Singapore Journal of Tropical Geography, 29: 117129.

Painter J. (2006). 'Prosaic geographies of stateness', Political Geography, 25(7): 752-774.

Parks, T. and Cole, W. (2010). 'Political settlements: Implications for international development policy and practice'. Occasional Paper No. 2. San Francisco: The Asia Foundation.

Pitcher, A., Moran, M. and Johnston, M. (2009). 'Rethinking patrimonialism and neopatrimonialism in Africa'. African Studies Review, 52(1): 125-156.

Robins, S., Cornwall, A. and von Lieres, B. (2008). 'Rethinking "citizenship" in the postcolony'. Third World Quarterly, 29(6): 1069-1086.

Roll, M. (2015). 'Pockets of effectiveness: Review and analytical framework', in M. Roll (ed.), The Politics of Public Sector Performance: Pockets of Effectiveness in Developing Countries. London: Routledge, pp.22-42.

Spivak, G. (1996). 'Subaltern talk: Interview with the editors', in D. Landry and G. Maclean (eds.), The Spivak Reader. London: Routledge, pp. 297-308.

Teichman, J. A. (2016). The Politics of Inclusive Development. Policy, State Capacity and Coalition Building. Basingstoke: Palgrave Macmillan.

Wai, Z. (2012). 'Neo-patrimonialism and the discourse of state failure in Africa', Review of African Political Economy, 39(131): 27-43.

Whitfield, L. and Therkilsden, O. (2011). 'What drives states to support the development of productive sectors? Strategies ruling elites pursue for political survival and their policy implications'. Danish Institute for International Studies Working Paper 2011: 15. Copenhagen: DIIS.

Wight, C. (1999). 'They shoot dead horses don't they? Locating agency in the agentstructure problematique', European Journal of International Relations 5(1): 109-142.

Wight, C. (2004). 'State agency: Social action without human activity', Review of International Studies 30(2): 269-280.

Young. C. (1994). The African Colonial State in Comparative Perspective. New Haven, CT: Yale University Press. 


\section{esid}

\section{The Effective States and Inclusive Development Research Centre}

The Effective States and Inclusive Development Research Centre (ESID) aims to improve the use of governance research evidence in decision-making. Our key focus is on the role of state effectiveness and elite commitment in achieving inclusive development and social justice.

ESID is a partnership of highly reputed research and policy institutes based in Africa, Asia, Europe and North America. The lead institution is the University of Manchester.

The other institutional partners are:

- $\quad$ BRAC Institute of Governance and Development, BRAC University, Dhaka

- $\quad$ Center for Democratic Development, Accra

- $\quad$ Center for International Development, Harvard University, Boston

- Department of Political and Administrative Studies, University of Malawi, Zomba

- $\quad$ Graduate School of Development, Policy \& Practice, Cape Town University

- Institute for Economic Growth, Delhi

In addition to its institutional partners, ESID has established a network of leading research collaborators and policy/uptake experts. 